\title{
Discussion of Human Cloning from Civil Law Point of View
}

\author{
Ebrahim Rostami \\ Master of Degree Course Student of Private Law, Department of Law \\ Bandar e Anzali International Branch, Islamic Azad University, Bandar e Anzali, Iran \\ Mohammadreza Sharafatpeima \\ Corresponding Author. PhD, Assistant Professor, Department of Private Law \\ Bandar Anzali Branch, Islamic Azad University, Bandar Anzali, Iran
}

\section{Doi:10.5901/mjss.2015.v6n6s6p72}

\begin{abstract}
Human cloning or human tagging (simulation) is a method in which human fetus is cloned for research in laboratory. In this method, after lapsing 5 days from forming sperm, special cells which named as fundamental cells are taken for cloning. These cells have ability to produce cell in human body. The aim of research is to discuss human cloning from civil law point of view. Based on data collected in Iran's law, there is not opposition with cloning, since treatment cloning can be origin services like prevention reproduce incomplete children, prevention from genetically diseases. But human cloning could not be cited as authorized method for human reproduction. In human cloning, the children cloned is intimate with one who given cell and this intimacy avoids from marriage. And about intimacy of children cloned, the children shall have Iranian nationality. About illegitimate as for unification scale, the illegitimacy and customary relation between children cloned and father are regarded in Iran's law. About legitimacy of children, issuance of forgery deed and heritage and other relatives are not difference by natural methods. The child cloned has not difference from other persons. In the case of lacking legitimacy of cloning, we believe that child doesn't heir from father and mother but in the case of marriage, he/she heirs.
\end{abstract}

Keywords: Cloning, Human Cloning, Civil Law

\section{Introduction}

Since human is following to know and we cannot prevent from him not develop, in other side, we cannot enter into another step but the religion shall confirm new thing till be the light of road. All physical, behavioral and thoughtful descriptions of human are resulted from genes in which genome exists and in other word, it is influenced genetics and the share of other factors like environment and culture is not stable, that means these factors are in the row of genetically factors. Religious inclinations, spouse selection, prevention adultery with intimates, are programmed in gene and what we want, are out of our supervision, so that out actions are follower genetic code and we cannot regard historical variations without consideration genetics dimension but they are cultural. Birth of human instead of usual methods was from dreams. In current years, publish successful news of genetic scientists' surprised world in animal cloning. Cloning is regarded as scientific great approach so that some of experts of international relations regarded it as a scientific revolution having incredible effect on world and international situation. Human cloning has different outcomes on personal and social life. Based on it, possibility of cloning motivated sensitivities and the owners of religion are involved and asked questions. It seems cloning caused challenges in civil law which needs solution (Guilhaudis.2002 -380,pp).

Cloning is one of the last human approaches which opened clear horizon into saint recognition and human can benefit from it without fear from human creation. (Karm, 1998, pp 12). Based on above, the researcher is following to find unknown points of cloning from civil law. And know what the theoretical base of opponent and proponents in civil law is.

\section{Theoretical Framework}

\subsection{History of Cloning}

In fact, history of cloning returned to third decade from century $20^{\text {th }}$ which was done on plants for first time but they did not success. At 1960, the plants have been cloned. At 1993, they did about animals and the Italia were success to 
produce the calves that were not similar as the cow which cloned with it but they had more similarities. Then at 1997, Professor Wilmot and et al, applied this method for mutton cloning in Razlin institute of Scotland and after 200 unsuccessful experiences, finally they produced mutton named Daly. Next, this method was applied on other mammals like monkey and cat. (Gharzavi, 2003, pp 23)

Finally, at 2002, Dr. Brigit informed the production of the first human cloned by manager of American company as Clonide. This girl child was born with cell of women skin 31 years old and born by cesarean at December 27, 2002. The child has been named as Hava and had $3.200 \mathrm{~kg}$ weight. This institute published informing about other humans cloned. (Deloei, 2005, pp 143)

Dr. Brigit regarded coning as dreamful part of human in a book that means eternality. The said institute performed DNA experiment under pressure of public and court on mother and child but these claims have not been proved and some of scientists regarded as juggle. (Sadeghi, 2007, pp 95)

In view of others, the cloning has been happened some years before informing, rapid development of genetically science enabled human to know this field.

\section{Define of Concepts and Idioms}

\subsection{Cloning}

Cloning is known as clonage in French and cloning in English. It is named as Klon or confer in Arabic, it is derived from Greece root like clone which is twig of wood which has been used by producer of flower for making new plants. The similarity of cloning to cutting is that in each method, production is done without zygosis. In cutting, the branches or roots which cutted, will be planted in another place. In cloning, zygosis is done without reproduction. (Mohajeri, 2002, pp 1,2)

\subsection{Human Cloning}

Human body consisted of cell which has all genetics descriptions which converts to human by special method and has human specifications. This special method is human cloning. (Makarem Shirazi, 2001, pp 22)

\subsection{Civil Law}

Civil law is sum of patterns which determine personality status of citizens, organize private ownership and main rights that the citizens obtain it and methods for transfer and its decline. (Saket, 1997, pp 42)

\section{Discussion Legal Point of Opponents and Proponents of Cloning Human Cloning}

After enhancing human cloning by informing new about it since some countries informed their status against it, Iran did not consider it and the official authorities did not act against it.

After some years, seldom lawyers and researchers considered it and it seems that without consideration of technology and discussion all aspects of it, we consider that.

\subsection{Views of Proponents of Cloning}

The lawyers believed that general legal elements are regarded as accepted by all nations and thus are part of international law and are acted in international relations and based on article 38 of association of the judiciary international bureau they are imperative without commitments which are as list of rights and freedom on world human right announcement and consider cloning without consideration the rights and believes that right of life inserted in article 3 of world human right announcement is considered with following reasons into opposition with human cloning and consent with treatment cloning. (Teymouri, 2005, pp29)

\subsection{Without Loss}

As first law in fundamental ethical elements of humans, without loss is so important and no one can loss other and regards conflict experimental cloning on human suppose. (Fakoor, 2009, pp 149) 


\subsection{Utilization}

This pattern is regarded as the second fundamental pattern in ethical field and cited that the hidden duties is about prevention from loss to others and move into promotion and prudence of international documents. But remedial cloning has not opposition. (Same)

\subsection{Ultimate of Human}

Based on this pattern which is cited as the third element, all human are ultimate and have human prestige, thus we are not authorized descend persons in the scale of things in order to supply our needs in bio technology and its result is to prevention from human cloning given is regarded as human fetus. About other cloning methods, its nature is not as tool usage and doesn't violate it.

\subsection{Views of Proponents of Cloning}

The lawyers believed that relation between cloning and technology is absolute private and public relation. (Rahimi, 2005, pp 62). In research or remedial cloning which is one of cloning, the zygosis fundamental cells are obtained and used for treatment. Since cloning is not solution for obtaining fundamental cells, the abortive textures are obtained from germs in laboratory as artificial in order to cure infertility or non sexual cells. (Fakooor, 20009, pp 151)

The jurisconsults want to apply this method by taking reasons like cure infertility, produce human fundamental cells, prevent from genetics disease and help to remove problems for supply grafting orgasms.

Since cloning is divided in two human and research methods and the work is similar but the result are different and the prevention actions are not intellectual, because by applying accurately and separation between cloning methods, this technology can be origin great services like prevention from imperfect children, prevention from genetics disease, provide possibility for grafting orgasms into society, so that the thinkers of ethics and sociology, philosophy and law like catholic church, orthodox, Jewish opposed it. But it seems that human cloning shall be prevented because of its disadvantages, but about remedial or research cloning which cited its applications, it shall be prescribed with special laws. There is not medical reason for its prevention and the research shall be supported in order to treat diseases. In current years, there is significant progress but there is not legal patronage for it. This legal gap can cause misuse from scientific researches in order to obtain illegitimate benefits and mental ownership of scientists shall be questioned. (Same, pp 154)

\subsection{Legal Verdicts of Cloned Child}

Regardless saint law of Islam regards sexual relation between man and woman out of marriage and their children are prohibited. Thus, the verdicts are considered about it.

Doubtless in future, human society will be host of new generation of humans which produced neither sexual reproduction but produced by cloning, so that this method is legitimate or not, thus necessity of discussion is non deniable. In this section, it is tried to discuss legal status of cloned persons by relative, maintenance, intimacy, nationality, surname, registration documents, and heritage as for Iran's law.

\subsection{Relative}

One of the basics subjects which is cited in legal status of cloned persons is parentage. In the case of determine legitimacy of parentage, the status will be recognized in another field. Relative ${ }^{1}$ means race, main, generation, family, train, vein and root. (Dehkhoda, 1994, pp 123) it is said that relative is personal relation to others with birth, (due to father) by relative like two brothers are due each other. (Langroudi, 1999, pp 154)

Dr. Naser Katouziyan said about proving relative: in order to prove necessary relative, it is necessary legitimacy which the relation is natural between child, woman and man, the intercourse is happened and the child is due to marriage, thus relation of father and mother is not renewable and has close relation. (Katouziyan, 2007, pp 39)

Relation is relatively affair between two people which one is another generation of two are from third generation and this is relative closeness and make natural relation. (Safee and Emami, 1995, pp 39) civil law did not define relative and suffice to define its symbols and it is cited in article 1158: the child belongs to husband in the time of birth if it is lower than 6 months from birth to intercourse and did not laps more than ten months. Article 1167 says about relative of child due to adultery: the child due to adultery doesn't belong to man. (Same) 


\subsection{Legal Nature of Relative}

\subsubsection{Matrimony}

Matrimony is cited as one of the main conditions of relative, this belief is from relative reason that accurate matrimony results to woman and man intercourse and make zygosis and birth and doesn't objection, but during history, there are exceptions. Based on thoughts of Koran, Hazrat Maryam had child without marriage and intercourse, the other exceptions are due to closeness to doubt. Civil law says in article 1165: child birth due to doubt belongs to party has mistaken and two parties mistake, child belongs to them. About matrimony in cloning, some of jurisonconsult regarded legitimate birth due to cloning. Thus, based on this belief, relative of cloning is regarded as legitimate. The important subject which is cited here, is that child cloned has one single parent and others regarded these children as illegitimate. The jurisconsults cited that closeness to doubt is due to person who has mistaken (Khomeini, 2007, pp 548) so that the child is mistaken.

\subsubsection{Spouses Intercourse}

One of the situations of relative is intercourse of spouses. In today world, the artificial fertility methods are done as if the intercourse is not done but medical methods are applied. Some of jursiconults certified it and regarded child ita $\mathrm{s}$ legitimate.

In this regard:

Dr. Deceased Shahdi regarded lacking knowing spouses due to zygosis, he says about the case fetus is injected to legal spouse:

In this case, it shall be said that child due to artificial zygosis belong to couple whether as zygosis or another person did it or based on their unawareness. As if stranger exit the fetus and inject it into another woman who is slept. (Shahidi, 1999, pp 146)

Article 1158 is regulated as if this case is term of intercourse:

The child born in the time of couple belongs to husband if it is lesser 6 months and more than ten months from intercourse to birth. It seems that civil law did not certify legitimate case. This reason is endless since as said before, intercourse between man and woman is due to legitimate which is made by bodily closeness between spouse and husband. (Katouziyan, 2001, pp11)

Other mistake which is about cloning is that during cloning, opposite sex doesn't intervene. Example, woman is voluntary for cloning and her non sexual cells are removed. These non sexual cells locate in their ovum and growth in womb. In this manner, child has one single parent. Regardless above, all cloning cases are as similar. Because genetics material which is ovum is effective in transfer genetics specifications and exit from ovum and ovum is used as a place for growth of non sexual cells, thus, in all cloning cases, genetically specifications are transferred merely. (Same)

\subsection{Relative of Child Cloned}

\subsubsection{Child Born from Doubtful Intercourse}

Some of jurisounsult regarded cloning as birth to doubt, thus we shall cite explanations about determine legal situation of children cloned.

Doubt is supposing instead of fact and close to doubt is a man intercourse with woman guessing they have couple relation whereas the relation is not and this relation is resulted to child.

Article 1165 of civil law says that the child born from this relation belongs to party who is mistaken and if two parties mistake, belong to them.

The child born from doubt intercourse has all rights like heritage, relative, intimacy and so on.

Based on idea of jourisoncounsult, children cloned are regarded as born in doubt and others regarded it as artificial zygosis.

We conclude that these children belong to father or mother like legitimate matrimony (man or woman which child cloned born from their non sexual cells) and the relative is legitimate. 


\subsubsection{Consent Imminence}

In Islam, there are institutes like consents which attributed as fake of relative and it has some of real relative not all. Based on regulations of Islamic jurist and civil law, a strange child who feed milk from woman can be regarded as child of woman and her husband under special situations and it is forbidden to marry between the child and brothers and sisters, that means consent to verdict and policy maker is like as natural relative. (Mehrpour, 2003, pp 176)

Consent imminence is barrier for matrimony which based on article 1046 limited to conditions out of discussion. At last, based on idea of some jurists, duet.

Cloning is regarded as consent child and cloned child will be same as child of own and cannot marry with brothers and sisters. But doesn't heir.

\subsubsection{Maintenance}

Civil law cited maintenance child in article 1168 to 1176, also, based on article 1168 of civil law, the parents shall maintain child. Maintenance is about protection and bodily and mental keep. The policy maker counted duties and tasks of receiver fetus as duties inserted in article 1169 (amendment 11.06.2003). In said law, the mother has priority in maintenance of child like boy and girl if the mother and father separated each other and after that, father has right. (Sadeghi Moghaddam, 2006, pp 175)

Sine cloning is new scientific phenomena, it is not inserted about its legal verdicts, thus we are force to refer into Islamic valid documents and legal pattern. Based on above, there are three theories:

First group: they believed that relative of son cloned is like as consent child.

Second group: they believed that relative of son cloned is like as born doubt.

Third group: they believed that relative of son cloned is like as child due to legitimate marriage.

Since second and third group are close, discuss their theories in first part and analyze belief of first group.

First and second group believed that maintenance children and education is from duties of parents. Civil law in article 168 cited that: maintenance of children is due to parents and maintenance means bodily protection so that mental and ethical protection is given in new Iran law. (Safee and Emami, 2002, pp 343). Some regarded maintenance as education and said: education means to ethical and mental nurture of children. (Same, pp 363)

Based on article 1046, consent intercourse is relatively from matrimony but in other cases like maintenance, heritage and profusion, verdicts pertinent to child not conform since based on article 1168 and 1178, person is entitled to maintain his own child, thus there is not duty about consent.

Theory of third group is about sons cloned in given said cases like child due to adultery. If cloning is due to maintenance and education, based on this commitment, the court forces person to do his duty but if there is not contract about it, who is keeper of child?

Since child needs protection and maintenance, and this case is imperative and parents are superior to others in keeping children and it seems that from social justice, maintenance is located in legal point of view and regarded as relative due to recognition of parents. (Emami, 1991, pp 182)

If father accepts implicit commitment for paying life costs of child due to adultery, thus, the courts sentences father to pay the costs without considering civil responsibility and prove fault. (Katouziyan, 2007, pp 40)

\subsubsection{Intimacy}

Relative and casual imminence is from barriers of matrimony and discussions about do cloned person can intercourse with person who cloned from him.

\subsection{Relative Imminence}

Civil law cited barriers of matrimony in chapter three and they are:

1- Relative imminence

2- Consent imminence

3- Casual imminence

4- Married woman

5- Third Divorce

6- Ninth Divorce 


\section{7- Matrimony with Pagan}

Civil law says in article 1045: it is forbidden to marry with following relatives although the imminence is due to doubt and adultery.

1- Matrimony with father and ancestors and mother

2- Matrimony with children what lesser

3- Matrimony with aunts and uncles and aunt and uncles of ancestor of father and mother

As displayed in above discussion, relative of children born are regarded as doubt and if we accept each, it has one result. Based on article 1046 and 1055 of civil law, these are barriers of matrimony in three cases:

Article 1055 says about prohibition of born to doubt, close to doubt and adultery is accurate if it is based on previous matrimony but it doesn't cancel previous matrimony. About adultery and close to doubt like previous matrimony, there is difference, but it regards close and intercourse like matrimony and civil law is following famous theory, thus, if person married with woman then his father and son intercourse with that woman, and this action was happened between mother in law and brother in law, woman will not be prohibited on him. (Abdeh, 1960, pp 281)

\subsection{Casual Imminence}

Contract of contracts mean to be groom, husband of girl of sister, to be relative with someone by giving and taking woman, groom, affair or interest which is made between women and husband which respect the affair, example, women of father or son are prohibited and mother in law and sister in law are illegal. (Moin, 1997, pp 4161)

Mr. Mohagegh Damad says casual imminence which is named as contractual as if defined by Shahid sani and Sheikh Ansari, is relative which is made based on matrimony between couples. (Mohaghghe Damad, 1990, pp 86)

Article 1047 prohibited three matrimonies as permanent:

1- There is relative or consent affair between man and mother of his ancestor

2- There is affair between father's woman and woman which is relative and the imminence is consent.

3- There is good relation between man with sons with any degree.

Based on unification vote of higher Supreme Court under no. 617- 12.07.1997, instead of heritage, illegitimate children have rights same as right of father, thus, if the relation is simulated, there is relation based on intimacy of child and father and mother based on article 1047.

\section{Nationality}

Since there are different factors in cloning which can determine nationality, thus, nationality subject has complicated case.

Nationality has two types:

Main or origin nationality: it is nationality which gives to person from time of birth, for example, based on paragraph 2 and issuance of article 967 of civil law, someone his father is Iranian like born in Iran or abroad, it is recognized as Iranian. There are two methods for obtaining nationality like soil and blood.

Acquisitive Nationality: this nationality is named as derivative and it is made after legal actions by her parents for example, person who is Iranian obtains another natiolaity because of marriage with other citizen.

\subsection{Nationality in terms of Iran's Law}

In this case, since maintenance of children is personality status and based on article 7 of civil law, the children shall devoted to it, but as for article 964 which regarded relations between children and parents under Iranian law, thus, it shall be proved that relative of cloned children is evident and maintenance is due to accuracy of relative. As for above, and since the claim is cited in Iran, firstly, based on Iran law about relative will be determined and there are two hypothesizes about nationality of cloned persons:

\subsection{Child has father}

In this manner, if father ( person who his non sexual cell has been used) is Iranian and according to paragraph 2 of article 976, someone has Iranian father like born in Iran or abroad, is regarded Iranian. In this manner, child cloned obtains Iranian nationality by blood and his nationality is original.

If father's of child is not Iranian the child cloned cannot be Iranian otherwise (child cloned) his father are born in 
Iran. Paragraph 4 of article 976 of civil law, persons who cloned from abroad parents in Iran, obtains Iranian nationality by soil method.

\subsection{Child has Mother}

In this manner, if mother born in Iran and child cloned born in Iran and according to paragraph 4 of article 976 of civil law is regarded as Iranian. And his nationality is known by soil method. In this status, mother nationality doesn't intervene in determination of nationality and what is important, place of birth of mother and child in Iran otherwise, he is not regarded as Iranian.

\subsection{Child Cloned bears in abroad of Iran}

As said before, in the case of recognition and obtaining consent imminence about cloned person with person his non sexual cells have been used. Based on article 1046 of civil law, consent imminence, is regarded as consent imminence, thus this process is not about other cases like nationality and the child cannot obtain nationality of parents. (Emami, 1991, pp 175)

\subsection{Surname and Civil Status}

Doubtless, the persons shall have surname and civil status instead of manner of birth to be recognizing by their prestige. In this discussion, there are two separated discussion about surname and civil status of persons who made by cloned. And will be analyzed based on Iran's law.

\subsection{Surname}

In order to recognize easily persons, we need surname. Article 997 of civil law cites about surname that: every one shall has surname.

Thus, having surname is imperative. Note of article 41 of civil law cited about surname:

Surname of children will surname of father although the identification card issued in other registry civil status, the subject about cloned children depends on previous discussion to know the relatives.

\subsection{Status Documents}

Based on article 12 and 13 of civil registration status, birth of child including his father and mother are Iranian or foreigner shall be registered by consulate representative and civil registration status. This birth is registered in general book and in this book, there is information about perfect time of birth, name and surname of the holder and gender, perfect specification of parents, perfect specification of informer who is another one, specification of witnesses and signature of representative of civil registration status. After registration birth, if child is Iranian, identification card will be issued and submitted and the announcement will be sent in page of mother and father and if child is foreigner, birth certificate is issued and if he is Iranian, civil documents will be issued. (Katouziyan, 2007, pp45)

\section{Conclusion}

Simulation of cloning is new phenomena in medical world and it is one of cases which stimulated many reactions. So that, it doesn't opposite with cloning but because of imperfect results, we shall be perfect about its outcomes.

Instead of usual reproduction of human which is done by sperm zygosis of man and ovule of woman into woman womb, in cloning, one of discriminated cells which has genetically properties transfer into woman ovum and the ovum transferred into womb of woman and locates till birth?

In our legal and civil law, since cloning is legitimate or not, child coned is intimate with father and mother and this intimacy prevents from matrimony, we predicate two hypothesizes in this case, by given relative of cloned person, in this manner, if father (person his non sexual cells have been used) has Iranian nationality and his parents born in Iran, that child is Iranian. By given consent or illegitimate, in this manner, be illegitimate and having customary relation between child cloned and his father, these children are Iranian based of vote of Supreme Court. In this case, if we regard illegitimate relative of child with his father again we used unified strategy and named as under surname of his father. 
If we regard relative of cloned child as legitimate, issuance of civil status doesn't different from persons who born naturally and in the lacking legitimacy of cloning, again based on that vote, civil status will be issued.

Cloned children have not different from other as nationality. In the case of relative of cloned children are regarded as legitimate, they share heritage with parents and in the case we believe in illegitimacy of cloning, the child doesn't heir from his parents, in this case he will heritage relation.

In global point of view, opponents of cloning believed in reasons like lacking medical security, hasty elderly, ethical pathology, imperfect humans and use of cloned humans as grafting orgasms. Against, the proponents believed that treatment of infertility, produce human fundamental cells, prevent from genetically diseases, help to remove problems for grafting and apply this method in servicing human life is important.

The writer believes this problem is without difficulty in couples affairs and don't change genetically. If the lawyers accept this verdict as for technologically development and scientific innovations ads for variety of human needs, we can prove efficiency and dynamism of legal systems and overcome on problems.

\section{References}

Abdeh brojerd, Mohammad, 1960, Generalities of Islamic Law, Tehran, Islamic Propaganda Press affiliated to University, second edition. Aliakbar Dehkhoda, 1994, Persian Dictionary, Tehran, Tehran University, first edition.

Emami Hassan, 1991, Civil Law, volume 3, Tehran, Eslamiyeh Bookshop.

Fakoor Hassan, 2009, Criminology Discussion of Human Cloning in Iran law, medial law journal, third year, no.1.

Gharzvi Yousef, 2003, Cloning, translate by Nouroddin Saadiyani, Dinpajohan Magazine, no.3.

Guilhaudis, Jean-François,(2002) Relations Internationals contemporariness, editions du juris-classeur, Paris.

Jafari Lnagroudi, Mohammadjafar, 1999, Period of Civil Law, Law of Liabilities, Tehran, Ganje Danesh Press.

Karem Seyedghanim, 1998, Derivation and Confer between Thinkers experiences, Cairo.

Katouziyan Naeser, 2007, Civil Law (family), Tehran, Ganje Danesh.

Katouziyan Naeser, 2007, Preface of law science.

Khomeini Seyedrohollah, 1997, Tahrirol Vasileh, Volume $4^{\text {th }}$.

Makarem shirazei Naser, 2001, New Confers, Second Volume, Qom, Imam Ali School Press.

Mehrpour, Hossein, 2003, Glance to legal and judicial status of artificial fertility, Legal Research Magazine of shahid Beheshti University. Mohagegh damad Mostafa 1989, Legal Discussion of Family Law, Tehran, Humanities Press.

Mohajeri Abdolrasoul, 2002, a Report about Cloning, Tehran, Women Studies Bureau.

Moin Mohammad, 1997, Moin Persian Dictionary, Tehran, Farhang Nima Press, First Edition.

Nouri deloei, Mohammdreza, 2005, From Transgenic Animals to Mammals cloned, Islam's views in Medicine, Research Deputy of Mashhad Medical sciences University.

Rahimi Habibollah, 2005, Remedial Cloning in Bio Ethics, Sum of Articles, Tehran Samt.

Sadeghi Mahmoud, 2007, Legal Discussion of Human Cloning, inserted in first legal medicine congress of Islamic Countries.

Sadgehi Moghadddam Mohammdhossein, 2006, Articles published under legal musts and law for presenting fetus into infertile couple, Tehran, Samt Press.

Sadgehi Moghadddam Mohammdhossein, 2006, Articles published under legal musts and law for presenting fetus into infertile couple, Tehran, Samt and Ebn-e-Sina Research Center

Safaee Hossein and Asadollah Emami, 1995, Family law, Tehran, Tehran University, second Volume, first edition.

Safeee Hossein and Emami Asadollah, 2002, Family law, volume 2, Tehran, Tehran University Press.

Saket Mohammdhossein, 1997, Personality and Prestige in Civil Law, Mashhad Gothenburg, Volume2.

Shahidi, Mahdi, 1999, Legal Articles, Tehran, Lawyer Press with cooperation Asre Hoghogh, Second Edition.

Teymouri Hassan, 2005, Discussion of Human Right about Cloning (sum of articles) second edition, Tehran, Samt Press. 